\title{
Matrix metalloproteinases and their inhibitors in the gastrointestinal cancers: current knowledge and clinical potential
}

This article was published in the following Dove Press journal:

Metalloproteinases In Medicine

2 August 2014

Number of times this article has been viewed

\section{Yi-Chun Yeh \\ Bor-Shyang Sheu}

Department of Internal Medicine, National Cheng Kung University Hospital, Tainan, Taiwan
Correspondence: Bor-Shyang Sheu Department of Internal Medicine, National Cheng Kung University Hospital, I38 Sheng Li Road, Tainan, Taiwan Tel +886 62353535 ext 2004 Fax +8866276 6175 Email sheubs@mail.ncku.edu.tw

\begin{abstract}
The matrix metalloproteinases (MMPs) family can degrade various components of the extracellular matrix and are implicated in a number of key normal processes. Aberrantly enhanced MMP proteolysis can lead to tumor growth, progression, and metastasis. Therefore, MMPs are considered important therapeutic and diagnostic targets for the treatment and detection of human cancers. This review summarizes the recent literature on MMPs and their inhibitors as diagnostic and prognostic predictors of gastrointestinal cancers, including esophageal squamous cell carcinoma, gastric cancer, colorectal cancer, hepatocellular carcinoma, and pancreatic cancer. Genetic and epigenetic alterations contribute to cancer progression and influence cancer susceptibility. Single nucleotide polymorphisms are the most common type of genetic variation, and can alter the expression and function of the encoded proteins. MicroRNAs are a family of small non-coding RNA molecules that function in post-transcriptional gene regulation. This review also focuses on the contribution of single nucleotide polymorphisms and microRNAs to the alteration of MMPs and their inhibitors.
\end{abstract}

Keywords: MMP, TIMP, gastrointestinal cancers, biomarker, SNP, miRNA

\section{Introduction}

The matrix metalloproteinases (MMPs) family is composed of several zinc-dependent enzymes that degrade proteins of the extracellular matrix. MMPs also regulate cell growth, survival, and migration by releasing several proteins such as growth factors, chemokines, and adhesion molecules. MMPs participate in many normal biological processes, such as embryonic development, organ morphogenesis, bone remodeling, and wound healing. ${ }^{1,2}$ Alteration of MMP expression and activation generally promotes hallmarks of tumor progression including angiogenesis, invasion, and metastasis, and correlates with shortened survival in a variety of different cancers. ${ }^{3-5}$

Common structures of MMPs include a pro-peptide, a catalytic domain, a hinge region, and a C-terminal hemopexin domain. According to structure and substrate specificity, the MMP family is classified into collagenases (MMP-1, MMP-8, MMP-13, and MMP-18), gelatinases (MMP-2 and MMP-9), stromelysins (MMP-3, MMP-10, and MMP-11), matrilysins (MMP-7 and MMP-26), membrane type MMPs (MMP-14, MMP-15, MMP-16, MMP-24, MMP-17, and MMP-25), and others (MMP-12, MMP-19, MMP-20, MMP-21, MMP-23, MMP-27, and MMP-28). 6,7

MMPs are inhibited by endogenous tissue inhibitors of metalloproteinases (TIMPs), which comprise a family of four protease inhibitors: TIMP-1, TIMP-2, TIMP-3, and TIMP-4. ${ }^{8}$ These TIMPs can principally modulate MMP activity and suppress the extracellular matrix turnover by forming 1:1 enzyme/inhibitor complexes. ${ }^{9}$ Disruption 
of this MMP/TIMP balance can result in tumor growth and metastasis. TIMP-1, TIMP-2, and TIMP-4 are present in soluble forms, while TIMP-3 is tightly bound to the matrix. TIMP-1 is the prototypic inhibitor for most of the MMP family members, but it is a poor inhibitor of the membrane type MMPs and MMP-19. ${ }^{10,11}$ TIMP-2 is unique in that it selectively interacts with membrane type $1 \mathrm{MMP}$ to facilitate the cell-surface activation of pro-MMP-2. ${ }^{10-12}$ Thus, TIMP-2 can serve to inhibit MMP activity and to promote cell surface activation of pro-MMP-2 by membrane type 1 MMP. TIMP-3 inhibits members of the ADAM family of proteases, although the mechanism for this inhibition appears to be distinct from that of MMP inhibition. ${ }^{13,14}$ The expression pattern of TIMP-4 seems to be distinguished from the other TIMPs. Because TIMP-4 messenger RNAs (mRNAs) are localized in the brain, heart of adult humans, ovaries, and skeletal muscle, it may be an important tissue-specific regulator of extracellular matrix remodeling. ${ }^{15,16}$

\section{MMPs and TIMPs in gastrointestinal cancers \\ Esophageal squamous cell carcinoma (ESCC)}

Increased levels of MMP-1-3, MMP-7, MMP-9-13, MMP-15, and TIMP-2-4 have been reported in the blood or tissue samples from ESCC patients. ${ }^{5,17-25}$ Overexpression of MMP-1 and MMP-2 in malignant tissues was significantly associated with depth of tumor invasion, lymph node metastasis, and clinical stage. ${ }^{17,21,22}$ Patients with higher MMP-1 expression had poorer disease-free survival. ${ }^{21,22}$ Immunohistochemical staining showed that high level MMP-9 expression in ESCC tissues correlated with tumor differentiation and lymph node status. ${ }^{23}$ Gelatin zymography showed that the activated form of MMP-3 and MMP-10 was more strongly expressed in tumors than in paired normal tissue. Moreover, MMP-3 and MMP-10 mRNA levels were higher in tumors than paired normal tissues for each compartment. ${ }^{19}$ Upregulation of MMP-10 was significantly associated with poorer disease-specific survival in early-stage ESCC (TNM stage I-IIA). In addition, multivariate analysis found that MMP-10 expression in tumor tissues was evaluated as a potential independent prognostic factor for early-stage ESCC patients. ${ }^{20} \mathrm{MMP}-13$ was strongly correlated in patients who had lymph node metastasis. Cell models indicated that $M M P-13$ expression was regulated by MUC1 through the Runx-2-binding site. ${ }^{26}$ The intensity of immunohistochemical staining of MMP-15 significantly positively correlated to the intratumoral angiogenesis of ESCC. In addition, MMP-15 immunochemical intensities significantly correlated to tumor size. ${ }^{27}$ TIMP-3 expression was significantly lower in ESCC tissues than in matched normal mucosa. ${ }^{25,28}$ Serum levels of MMP-3, MMP-2, MMP-7, MMP-9, MMP-13, and TIMP-2 were examined in a number of studies. A study that included 53 ESCC patients and 92 healthy controls showed that serum level of TIMP-2 in the ESCC patients was significantly higher than in the control group, and was associated with patients' survival. ${ }^{29}$ Another study revealed that patients with ESCC had significantly higher serum MMP-3, MMP-7, and MMP-9 titers than the healthy controls. Based on the optimal cutoff values for MMPs by a receiver operating characteristic, the elevated MMP-3 and MMP-9, but not MMP-7, correlated with distant metastasis and poor survival. ${ }^{5}$ The serum level of MMP-13 was measured in 112 healthy controls and 141 ESCC patients and it was revealed that patients with an elevated level of MMP-13 ( $\geq 76.4 \mathrm{ng} / \mathrm{mL}$ ) had a significantly lower 5-year survival rate than those with non-elevated MMP-13 (<76.4 ng/mL) (Table 1). ${ }^{24}$

\section{Gastric cancer (GC)}

In $\mathrm{GC}$, increased levels of MMP-1-3, MMP-7, MMP-9, MMP-12, MMP-14, MMP-21, MMP-24, MMP-25, and TIMP-1-3 have been reported in blood or tissue samples. ${ }^{30-34}$ Tissue levels of MMP-3, MMP-7, MMP-12, MMP-14, and TIMP-3 were examined by using immunohistochemical staining. The expression of TIMP-3 was significantly higher, whereas that of MMP-3 and MMP-3/TIMP-3 was lower, in GC tissue of an early-stage group compared with an advanced-stage group. ${ }^{30}$ In intramucosal cancers, cag pathogenicity island-dependent MMP-7 upregulation was associated with carcinogenesis. ${ }^{35} \mathrm{MMP}-12$ expression was increased in GC compared with that observed in normal tissues. Increased MMP-12 and MMP-21 expression was associated with tumor invasion, distant metastasis, and TNM stage. Moreover, GC patients with MMP-12-positive expression or higher MMP-21 tended to have worse overall survival. ${ }^{32,36}$ MMP-14 expression correlated with small tumor size, tumor at distal stomach, and increased recurrence risk. MMP-14-positive expression was a risk factor related to poor prognosis. ${ }^{37}$ Serum levels of MMP-1, MMP-3, MMP-7, and TIMP-1 were higher in GC patients than in the healthy controls. ${ }^{3,38}$ Serum MMP-1 and TIMP-1 levels were positively associated with morphological appearance, tumor size, depth of wall invasion, lymph node metastasis, liver metastasis, perineural invasion, and pathological stage. ${ }^{38}$ Concomitant elevated MMP-3 (>14 ng/mL) and MMP-7 (>4.5 ng/mL) 
Table I Expression of MMPs and TIMPs in gastrointestinal cancers

\begin{tabular}{|c|c|c|c|}
\hline MMPs/TIMPs & Sample type & Method of analysis & Correlation \\
\hline \multicolumn{4}{|c|}{ Esophageal squamous cell carcinoma } \\
\hline MMP-I & Tissue $^{21,22,104}$ & $\mathrm{IHC} ; 21,22 \mathrm{M}^{22,104}$ & Regional lymph node; ${ }^{21}$ TNM stage; ${ }^{21}$ poor survival ${ }^{21,22}$ \\
\hline MMP-2 & Tissue $;{ }^{17}$ serum ${ }^{29}$ & IHC; ${ }^{17}$ ELISA ${ }^{29}$ & $\begin{array}{l}\text { Tumor invasion depth; }{ }^{17} \text { tumor-node-metastasis stages; }{ }^{17} \\
\text { lymph node metastasis }\end{array}$ \\
\hline MMP-3 & Serum; ${ }^{5}$ tissue ${ }^{19,104}$ & $Z ;{ }^{19}$ qRT-PCR; ${ }^{19} M^{104}$ & Poor survival ${ }^{5}$ \\
\hline \multicolumn{4}{|l|}{ MMP-7 } \\
\hline MMP-9 & Serum; ${ }^{5,18}$ tissue $^{17,23,104}$ & ELISA; ; ${ }^{5,18} \mathrm{IHC} ;{ }^{17,23} \mathrm{M}^{104}$ & Differentiation; ${ }^{23}$ lymph node metastasis; ${ }^{23}$ poor survival ${ }^{5,23}$ \\
\hline MMP-IO & Tissue $19,20,104$ & $Z_{;} ; 8$ qRT-PCR; ${ }^{19,20}$ IHC; ${ }^{19,20}$ M $^{104}$ & Lymph node metastasis; ${ }^{20}$ TNM stage; $;{ }^{20}$ poor survival ${ }^{20}$ \\
\hline MMP-II & Tissue $^{104}$ & $M^{104}$ & \\
\hline MMP-I2 & Tissue $^{104}$ & $M^{104}$ & \\
\hline MMP-I3 & Serum; ${ }^{24}$ tissue ${ }^{26,104}$ & IHC; ${ }^{26}$ ELISA; $;{ }^{24} \mathrm{M}^{104}$ & Lymph node metastasis; ${ }^{26}$ poor survival ${ }^{24}$ \\
\hline MMP-I4 & Tissue $^{87}$ & $\mathrm{IHC}^{87}$ & $\begin{array}{l}\text { Depth of wall invasion; }{ }^{87} \text { lymph node metastasis } ;{ }^{87} \text { tumor } \\
{\text { stage } ;{ }^{87} \text { survival; }{ }^{87} \text { recurrence }}^{87}\end{array}$ \\
\hline MMP-I5 & Tissue $^{27}$ & $\mathrm{IHC}^{27}$ & Tumor size ${ }^{27}$ \\
\hline TIMP-2 & Serum 29 & ELISA $^{29}$ & \\
\hline TIMP-3 & Tissue $^{25}$ & $\mathrm{IHC}^{25}$ & \\
\hline TIMP-4 & Tissue $^{25}$ & $\mathrm{IHC}^{25}$ & \\
\hline \multicolumn{4}{|l|}{ Gastric cancer } \\
\hline MMP-I & Tissue ${ }^{31}$ serum $^{38}$ & RT-PCR; ;1 IHC;;1 ELISA ${ }^{38}$ & $\begin{array}{l}\text { Tumor size; }{ }^{38} \text { depth of wall invasion; } ;{ }^{38} \text { lymph node } \\
\text { metastasis } ;{ }^{31,38} \text { liver metastasis; }{ }^{38} \text { advanced stage }{ }^{38}\end{array}$ \\
\hline MMP-2 & Tissue $^{33}$ serum $^{39}$ & qRT-PCR; ${ }^{33}$ ELISA $^{39}$ & Advanced-stage $\mathrm{e}^{33}$ \\
\hline MMP-3 & Tissue $;^{30}$ serum $^{3}$ & $\mathrm{IHC} ;{ }^{30} \mathrm{ELISA}^{3}$ & $\begin{array}{l}\text { Invasion; }{ }^{30} \text { lymph node invasion } ;{ }^{3} \text { metastasis } ;{ }^{30} \text { advanced- } \\
{\text { stage } ;{ }^{30} \text { poor survival }}^{3}\end{array}$ \\
\hline MMP-7 & $\begin{array}{l}\text { Peritoneal lavage } \\
\text { fluid; } ; \text { tissue } ; 3^{35} \text { serum }{ }^{3}\end{array}$ & qRT-PCR; ${ }^{34}$ IHC; $^{35}$ ELISA $^{3}$ & Lymph node invasion; ${ }^{3}$ poor survival; ${ }^{3}$ recurrence ${ }^{34}$ \\
\hline MMP-I2 & Tissue $^{32}$ & $\mathrm{IHC}^{32}$ & 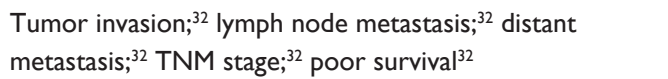 \\
\hline MMP-2I & Tissue $^{36}$ & $\mathrm{IHC}^{36}$ & Invasion; ${ }^{36}$ metastasis ${ }^{36}$ poor survival ${ }^{36}$ \\
\hline MMP-24 & Tissue $^{33}$ & qRT-PCR ${ }^{33}$ & Advanced stage $\mathrm{e}^{33}$ \\
\hline MMP-25 & Tissue $^{33}$ & qRT-PCR ${ }^{33}$ & Advanced stage ${ }^{33}$ \\
\hline MMP-I4 & Tissue 33,37 & $\mathrm{IHC} ; ;^{37} \mathrm{WB}^{33}$ & $\begin{array}{l}\text { Advanced stage, }{ }^{33} \text { tumor size; }{ }^{37} \text { increased recurrence } \\
{\text { risk } ;{ }^{37} \text { poor survival }}^{37}\end{array}$ \\
\hline TIMP-I & Serum ${ }^{38}$ & ELISA $^{38}$ & 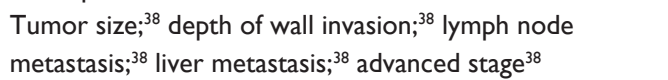 \\
\hline TIMP-2 & Serum 39 & ELISA $^{39}$ & Depth of wall invasion ${ }^{39}$ \\
\hline TIMP-3 & Tissue $^{30,33}$ & $\mathrm{IHC}^{30} \mathrm{WB}^{33}$ & Advanced stage $;^{30,33}$ invasion; ${ }^{30}$ metastasis ${ }^{30}$ \\
\hline \multicolumn{4}{|l|}{ Colorectal cancer } \\
\hline MMP-I & Tissue $^{44}$ & $\mathrm{IHC}^{44}$ & Poor survival ${ }^{44}$ \\
\hline MMP-2 & Tissue $^{43,44,105}$ & $Z^{\prime} ; 05$ ELISA $^{43}$ & Cancer presence; ${ }^{105}$ poor survival ${ }^{43}$ \\
\hline MMP-7 & Tissue $^{106}$ & $\mathrm{IHC}^{106}$ & Poor prognosis ${ }^{106}$ \\
\hline MMP-8 & Serum ${ }^{45}$ & TR-IFMA ${ }^{45}$ & Tumor stage $;^{45}$ distant metastases ${ }^{45}$ \\
\hline MMP-9 & Tissue $^{43,44,107}$ & IHC; ${ }^{107}$ ELISA $^{43}$ & Recurrence; ${ }^{107}$ poor survival ${ }^{43}$ \\
\hline MMP-I3 & Tissue $^{41}$ & qRT-PCR ${ }^{41}$ & Liver metastasis ${ }^{41}$ \\
\hline MMP-2I & Tissue $^{42}$ & $\mathrm{IHC}^{42}$ & Poor prognosis ${ }^{42}$ \\
\hline MMP-I4 & Tissue ${ }^{40}$ & qRT-PCR ${ }^{40}$ & Survival ${ }^{40}$ \\
\hline TIMP-I & Tissue; ${ }^{108}$ serum $^{46}$ & IHC; ${ }^{108}$ ELISA $^{46}$ & Poor prognosis; ${ }^{108}$ tumor stage; survival|46 \\
\hline \multicolumn{4}{|c|}{ Hepatocellular carcinoma } \\
\hline MMP-I & Tissue $^{49}$ & $\mathrm{IHC}^{49}$ & Recurrence; ${ }^{49}$ poorer survival $\left.\right|^{49}$ \\
\hline MMP-2 & Tissue $^{47}$ & $\mathrm{IHC}^{47}$ & Lymph node metastasis $^{47}$ \\
\hline MMP-8 & Serum ${ }^{51}$ & TR-IFMA ${ }^{51}$ & Survival| $\left.\right|^{51}$ \\
\hline MMP-9 & Tissue ${ }^{48}$ serum $^{51}$ & $\mathrm{IHC}^{48}$ ELISA $^{51}$ & Recurrence ${ }^{48}$ survival ${ }^{48,51}$ \\
\hline MMP-I2 & Tissue $^{51}$ & qRT-PCR ${ }^{51}$ & Recurrence; $^{51}$ survival ${ }^{51}$ \\
\hline TIMP-I & Serum ${ }^{51}$ & ELISA $^{51}$ & Survival ${ }^{51}$ \\
\hline \multicolumn{4}{|l|}{ Pancreatic cancer } \\
\hline MMP-2 & Tissue $^{109}$ & $Z^{109}$ & \\
\hline MMP-9 & Tissue $^{109}$ & $Z^{109}$ & High tumor grades 109 \\
\hline TIMP-I & Serum ${ }^{52}$ & ELISA $^{52}$ & Early stage ${ }^{52}$ \\
\hline
\end{tabular}

Abbreviations: ELISA, enzyme-linked immunosorbent assay; IHC, immunohistochemistry; M, microarray; MMP, matrix metalloproteinase; RT-PCR, reverse transcription polymerase chain reaction; q, quantitative; TIMP, tissue inhibitor of metalloproteinase; TR-IFMA: time-resolved immunofluorometric assay; WB, Western blot; Z, zymogram. 
independently correlated with lymph node invasion and are predictive of shorter 2- or 5-year survivals. ${ }^{3}$ Inversely, serum levels of MMP-2 and TIMP-2 were lower in GC patients than in healthy subjects. Concentrations of TIMP-2 and carcinoembryonic antigen correlated with depth of wall invasion (Table 1). ${ }^{39}$

\section{Colorectal cancer (CRC)}

MMP-1, MMP-2, MMP-7, MMP-9, MMP-13, MMP-14, MMP-21, and TIMP-1 expression in CRC were examined. ${ }^{40-44}$ Levels of MMP-1 in tumor-free mucosa tissue were significantly associated with cancer-specific survival in CRC in univariate analysis. This prognostic strength was maintained for MMP-1 and N-status in multivariate analysis. ${ }^{44} \mathrm{~A}$ high protein expression of MMP-2 as well as MMP-9 in normal mucosa was found to correlate with worse 5-year survival. ${ }^{43}$ Expression levels of $M M P-7$, $M M P-9, M M P-13$, and TIMP-1 were higher in cancer tissue than in adjacent normal mucosa. MMP-13 expression correlated with liver metastasis. ${ }^{41} M M P-14$ gene expression was higher in cancer tissue than in adjacent normal mucosa. Overall 5-year survival differed significantly between patients with high $M M P-14$ gene expression and those with low expression. ${ }^{40}$ MMP-21 expression was significantly higher in CRC as compared with in normal epithelial tissue, and correlated with tumor invasion, lymph node metastasis, and distant metastasis. Moreover, MMP-21 was also proven to be an independent prognostic factor in patients with stage II as well as stage III CRC. ${ }^{42}$ A study of 48 CRC patients and 83 healthy controls showed that serum levels of MMP- 8 were higher in the patients than those in the controls and positively correlated with disease stage, the degree of primary tumor necrosis, and blood neutrophil count. ${ }^{45}$ Serum MMP-9 and TIMP-1 were measured and significantly higher in CRC patients than in healthy subjects. Concentrations of TIMP-1 correlated with tumor stage, nodal involvement, presence of distant metastases, and patient survival (Table 1). ${ }^{46}$

\section{Hepatocellular carcinoma (HCC)}

Protein or mRNA levels of $M M P-1, M M P-2, M M P-9$, and $M M P-12$ were examined in HCC subjects. ${ }^{47-49}$ MMP-1 and PAR-1 levels were high in HCC tissues compared with normal liver tissues. The overexpression of MMP-1 and PAR-1 was significantly associated with recurrence, TNM staging, and portal vein invasion of $\mathrm{HCC}$ as well as significantly poorer overall survival and disease-free survival. ${ }^{49}$ Upregulated MMP-9 was associated with both time to recurrence and overall survival. ${ }^{48} \mathrm{MMP}-12 \mathrm{mRNA}$ was significantly higher in HCC tissues than in non-tumor and normal liver tissues. Overexpression of MMP-12 mRNA significantly correlated with presence of venous infiltration, early tumor recurrence, and poor overall survival of HCC patients. ${ }^{50}$ Patients with higher concentrations of serum MMP-8 or TIMP-1 had a significantly worse overall survival than patients with low concentrations of serum MMP-8 or TIMP-1. The overall survival in patients with a high ratio of MMP-9/TIMP-1 was statistically significantly better than in those patients with a low ratio of MMP-9/TIMP-1 (Table 1). ${ }^{51}$

\section{Pancreatic cancer}

Serum level of TIMP-1 was higher in pancreatic ductal adenocarcinoma than in chronic pancreatitis or healthy control subjects, and was correlated with reduced patient survival (Table 1)..$^{52}$

\section{Genetic and epigenetic regulation of MMPs and TIMPs}

Carcinogenesis is a complex process during which cells undergo genetic and epigenetic alterations. Genetic polymorphism is an important determinant of endogenous causes of cancer. Single nucleotide polymorphism (SNP) is the most common type of genetic variation. SNPs can alter the expression and function of the encoded proteins. A number of SNPs have been identified in the genes encoding MMPs and TIMPs. These SNPs have been associated with susceptibility to some diseases, including gastrointestinal cancers as summarized in Table 2.

Epigenetic alterations can lead to modified gene expression, including DNA methylation, histone modification, and microRNAs (miRNAs). miRNAs have become increasingly important to gene regulation. miRNAs are small non-coding RNAs of 18-25 nucleotides that negatively regulate gene expression through base pair matching with the 3'-untranslated region of their target mRNAs and resulting translation repression or degradation. ${ }^{53,54}$ Many studies have verified that miRNAs regulate cell proliferation, cell invasion, and cell apoptosis. ${ }^{5-57}$ Many miRNAs may function as both oncogenes and tumor suppressors, and abnormal expression of miRNA is associated with a variety of human cancers. A growing number of miRNAs have been identified to regulate MMP or TIMP expression directly or indirectly via other regulatory factors, resulting in a disruption of distinct MMP functions. These functions are involved in several of the processes - such as extracellular matrix remodeling, epithelial to mesenchymal transition, and angiogenesis - that 
support cancer progression. In gastrointestinal cancers, some recent data are summarized in Table 3.

\section{SNPs of MMPs and TIMPs and gastrointestinal cancer susceptibility}

The $M M P-1$ promoter region at position -1607 contains $1 \mathrm{G}$ and $2 \mathrm{G}$ SNPs relative to the transcriptional start site. The insertion of an additional $\mathrm{G}$ results in an ETS-1 binding site, and it has been shown that the $2 \mathrm{G}$ allele has higher transcriptional activity compared with the $1 \mathrm{G}$ allele. ${ }^{58}$ In a study of an Iranian population with CRC, individuals with the $2 \mathrm{G} / 2 \mathrm{G}$ genotype seemed to spread metastasis 3 years earlier than those who were $1 \mathrm{G} / 1 \mathrm{G}$ and $1 \mathrm{G} / 2 \mathrm{G} \cdot{ }^{59}$ In a Chinese population, there were no significant differences in the genotype and allele frequency of the MMP-1 -1607 $1 \mathrm{G} / 2 \mathrm{G}$ variant between the case group $(\mathrm{n}=237)$ and healthy controls $(\mathrm{n}=252) .{ }^{60}$ Another study of Indian cases with GC $(\mathrm{n}=145)$ and healthy controls $(\mathrm{n}=145)$ demonstrated that the $M M P-1-422 \mathrm{~T}>\mathrm{A}$ SNP showed significant risk for regional lymph node metastasis. In addition, the $M M P-1-519 \mathrm{~A}>\mathrm{G}$ SNP displayed poor cellular differentiation, attributing to a higher risk of cancer progression. ${ }^{61}$

Two SNPs in the $-1306 \mathrm{C}>\mathrm{T}$ and $-735 \mathrm{C}>\mathrm{T} M M P-2$ promoter region may influence MMP-2 expression. In vitro experiments showed that the $-1306 \mathrm{~T}$ and $-735 \mathrm{~T}$ alleles had lower promoter activity than the $-1306 \mathrm{C}$ and $-735 \mathrm{C}$ alleles, resulting from $\mathrm{C}$ to $\mathrm{T}$ transitions that abolished $\mathrm{Sp} 1$ binding. ${ }^{62}$ These two SNPs were associated with $M M P-2$ polymorphisms and ESCC in a Chinese population. Only the allele and genotype distributions of the $M M P-2-1306 \mathrm{C}>\mathrm{T}$ SNP had significant differences between patients with ESCC and healthy controls. Individuals with the $-1306 \mathrm{C} / \mathrm{C}$ genotype had a significantly increased risk of ESCC, especially those who smoked or had positive family history. ${ }^{63}$ The $M M P-2-1036 \mathrm{C}>\mathrm{T}$ SNP

Table 2 SNPs of MMPs and TIMPs in gastrointestinal cancers

\begin{tabular}{|c|c|c|c|c|}
\hline Gene & SNP (rs number) & Cancer type & Ethnicity & Comments \\
\hline \multirow[t]{3}{*}{ MMP-I } & $-422 \mathrm{~T}>\mathrm{A}(\mathrm{rs} 475007)$ & GC & Indian ${ }^{61}$ & $\begin{array}{l}\text { T carrier showed significant risk for regional } \\
\text { lymph node metastasis }\end{array}$ \\
\hline & $-519 A>G(r s \mid 144393)$ & GC & Indian 61 & $\begin{array}{l}\text { G carrier displayed poor cellular differentiation } \\
\text { attributing to a higher risk of cancer progression }\end{array}$ \\
\hline & $-|607| G>2 G(r s|| 2925 \mid 7)$ & CRC & Iranian 59 & 2G/2G genotype with invasion risk of CRC \\
\hline \multirow[t]{3}{*}{ MMP-2 } & $-1306 C>T(r s 243865)$ & ESCC & Chinese $^{63}$ & $\begin{array}{l}\text { C/C genotype correlated with increased risk of } \\
\text { ESCC }\end{array}$ \\
\hline & & CRC & Netherlander ${ }^{64}$ & $\mathrm{~T} / \mathrm{T}$ genotype was associated with poor survival \\
\hline & $-1575 G>A(r s 243866)$ & CRC & Taiwanese $^{67}$ & $\begin{array}{l}\text { A/A genotype had a } 6.32 \text {-fold higher risk of } \\
\text { developing distant metastasis }\end{array}$ \\
\hline MMP-3 & $-16125 A>6 A(r s 35068180)$ & $\mathrm{HCC}$ & Japanese ${ }^{69}$ & $5 \mathrm{~A}$ carriers had a significantly poorer prognosis \\
\hline \multirow[t]{5}{*}{ MMP-7 } & $-|8| A>G(r s|| 5688 \mid 8)$ & ESCC & Indian ${ }^{72}$ & G/G genotype carries a higher risk of ESCC \\
\hline & & GC & Indian ${ }^{73}$ & $\begin{array}{l}\text { G/G genotype was associated with a more than } \\
\text { two-fold increased risk of GC }\end{array}$ \\
\hline & & GC & Japanese ${ }^{70}$ & G carrier associated with an increased risk for \\
\hline & & & & Helicobacter pylori-related noncardial GC \\
\hline & & CRC & Pole $^{71}$ & $\begin{array}{l}\text { G/G had an increased risk of CRC, higher lymph } \\
\text { node involvement, and advanced tumor infiltration }\end{array}$ \\
\hline \multirow[t]{5}{*}{ MMP-9 } & P574R (rs2250889) & ESCC & Chinese $^{79}$ & $\begin{array}{l}\text { G/G genotype was associated with a significantly } \\
\text { increased risk of ESCC }\end{array}$ \\
\hline & & GC & Chinese $^{80}$ & $\mathrm{P} / \mathrm{P}$ associated with lymph node metastasis \\
\hline & R279Q (rs I7576) & GC & Chinese $^{80}$ & $R / R$ associated with lymph node metastasis \\
\hline & & CRC & Chinese $^{60}$ & $R / R$ associated with an increased risk of CRC \\
\hline & $-1562 C>T(r s 34016235)$ & CRC & Korean $^{82}$ & $\mathrm{C} / \mathrm{C}$ associated with higher risk of $\mathrm{CRC}$ \\
\hline$M M P-I 2$ & $-82 A>G(r s 2276109)$ & CRC & Swedish $^{85}$ & $\begin{array}{l}\text { A/A genotype is connected with a higher risk of } \\
\text { disseminated } C R C\end{array}$ \\
\hline \multirow[t]{2}{*}{ MMP-I4 } & $6767 \mathrm{G}>\mathrm{A}(\mathrm{rs} 1042704)$ & $\mathrm{HCC}$ & Taiwanese $^{86}$ & G/G genotypes had higher risk of HCC \\
\hline & $7096 \mathrm{~T}>\mathrm{C}(\mathrm{rs} 2236307)$ & $\mathrm{HCC}$ & Taiwanese $^{86}$ & $\mathrm{~T} / \mathrm{T}$ genotypes had higher risk of $\mathrm{HCC}$ \\
\hline \multirow[t]{3}{*}{ TIMP-2 } & $303 C>T(r s 2277698)$ & GC & German $^{65}$ & $\begin{array}{l}\text { C/C genotype associated with higher lymph node } \\
\text { metastasis and more distant metastasis }\end{array}$ \\
\hline & & CRC & Korean $^{82}$ & $\mathrm{C} / \mathrm{C}$ associated with higher risk of $\mathrm{CRC}$ \\
\hline & $-4 \mid 8 G>C(r s 8 \mid 79090)$ & CRC & Korean $^{82}$ & $\begin{array}{l}\text { G/G associated with higher risk of } C R C \text { and } \\
\text { metastasis }\end{array}$ \\
\hline
\end{tabular}

Abbreviations: CRC, colorectal cancer; ESCC, esophageal squamous cell carcinoma; GS, gastric cancer; HCC, hepatocellular carcinoma; MMP, matrix metalloproteinase; PC, pancreatic cancer; rs, reference single nucleotide polymorphism cluster identification; SNP, single nucleotide polymorphism; TIMP, tissue inhibitor of metalloproteinase. 
was examined in a Dutch population with CRC. Individuals with the $M M P-2-1036 \mathrm{~T} / \mathrm{T}$ genotype were associated with poor survival as compared with the $\mathrm{C} / \mathrm{C}$ and $\mathrm{C} / \mathrm{T}$ genotypes. Higher MMP-2 expression in tumors also correlated with poor prognosis. However, MMP-2 protein levels in CRC homogenates did not correlate with their respective SNP genotypes. ${ }^{64}$ Studies of a Korean population with CRC and a German population with GC showed that there were no significant differences in the genotype distributions and allele frequencies of MMP-2 -1036C $>\mathrm{T}$ between cases and healthy controls. ${ }^{65,66}$ A cohort of 282 CRC patients in a Taiwanese population was examined for $M M P-2$ SNPs, including $-1575 \mathrm{G}>\mathrm{A}$ and $-375 \mathrm{C}>\mathrm{T}$. Patients carrying the A/A genotype had a 6.32fold higher risk of developing distant metastasis. ${ }^{67}$

The promoter region of $M M P-3$ located at nucleotide position -1612 is characterized by a $5 \mathrm{~A} / 6 \mathrm{~A}$ polymorphism relative to the transcriptional start site, with one allele having $6 \mathrm{~A}$ and the other having $5 \mathrm{~A}$ at the polymorphic site. In vitro experiments showed that the $5 \mathrm{~A}$ allele has greater promoter activity than the $6 \mathrm{~A}$ allele. ${ }^{68}$ In a Japanese population with HCC, it was shown that MMP-3-1612 5A carriers had significantly larger $\mathrm{HCC}$ diameters and poorer prognosis than MMP-3 -1612 6A homozygotes. ${ }^{69}$

The susceptibility of the $M M P-7-181 \mathrm{~A}>\mathrm{G}$ SNP to cancer was examined in several studies. ${ }^{70-73}$ Functional analysis has shown that the promoter activity of the $-181 \mathrm{G}$ allele was two- to three-fold higher than that of the $-181 \mathrm{~A}$ allele. ${ }^{74}$ Computer analysis revealed that the $-181 \mathrm{G}$ site coincides with a putative binding site (NGAAN) for a heat shock transcription factor, which is not present in the $-181 \mathrm{~A}$ allele. ${ }^{74,75}$ Individuals with the $M M P-7-181 \mathrm{G} / \mathrm{G}$ genotype had a higher risk of ESCC in an Indian population. ${ }^{72}$ Two studies reported on the $M M P-7-181 \mathrm{~A}>\mathrm{G}$ SNP in relation to $\mathrm{GC}$ susceptibility. A study of 108 GC patients and 195 healthy controls in an Indian population showed that the $\mathrm{G} / \mathrm{G}$ variant genotype of the $M M P-7-181 \mathrm{~A}>\mathrm{G}$ SNP was associated with a more than two-fold increased risk of GC compared with the common A/A genotype. Smoking or a high intake of salted tea was not influenced by the $M M P-7$ polymorphism. ${ }^{73}$ Similarly, a study from a Japanese population showed that the $M M P-7-181 \mathrm{G}$ allele carrier relative to the A/A genotype significantly increased the risk of Helicobacter pylori related GC, especially in patients with noncardial cancer. ${ }^{70}$ A study of 184 Polish CRC patients showed that the G/G genotype had an increased risk of CRC and higher lymph node involvement than the A/A genotype. Moreover, the G/G genotype was associated with advanced tumor infiltration. ${ }^{71}$ In a German population, it was shown that there were no significant differences in the genotype distributions and allele frequencies of $M M P-7-181 \mathrm{G}>\mathrm{C}$ between $\mathrm{GC}$ patients and healthy controls. ${ }^{65}$

There is evidence indicating that the $-1562 \mathrm{C}>\mathrm{T}$ SNP in the $M M P-9$ gene promoter has an effect on $M M P-9$ expression, with the $\mathrm{T}$ allele having 1.5 -fold higher promoter activity than the $\mathrm{C}$ allele. ${ }^{76}$ In the coding region of the $M M P-9$ gene, non-synonymous SNP R279Q ( $G$ to A) at exon 6 may cause the amino acid change required for binding to its substrate and affecting its binding ability. ${ }^{77}$ In addition, non-synonymous SNP P574R at exon 10 (C to $\mathrm{G}$ ) has been shown to be functional in lung cancer. ${ }^{78}$ A Chinese study showed the P574R $\mathrm{G} / \mathrm{G}$ genotype was associated with a significantly increased risk of ESCC compared with the C/C genotype. ${ }^{79}$ In a Chinese population, the homozygous MMP-9 279R/R and 574P/P genotypes were associated with lymph node metastasis, but not with the occurrence of GC. ${ }^{80}$ Also in a Chinese population, the $\mathrm{R} / \mathrm{R}$ genotype of $M M P-9279 \mathrm{Q}>\mathrm{R}$ was associated with a 2.2-fold increased risk of CRC as compared with the QQ genotype. ${ }^{60}$ However, an inconsistent result from another Chinese study showed that P574R and R668Q of MMP-9 were not associated with $\mathrm{CRC}$ risk. ${ }^{81}$ In Korea, the homozygous MMP-9-1562 C/C genotype was significantly more frequent in CRC patients than in healthy controls. ${ }^{82}$

The $-82 \mathrm{~A}>\mathrm{G}$ SNP at in the promoter of the $M M P-12$ gene is located at a core recognition sequence of AP-1. In vitro experiments showed that the A allele increased the binding ability of AP-1 to enhance the gene transcription. ${ }^{83}$ Functional analysis of $M M P-13-77 \mathrm{~A}>\mathrm{G}$ SNP may lead to alterations in the gene expression. ${ }^{84} \mathrm{~A}$ Swedish study showed that the $M M P-12-81 \mathrm{~A} / \mathrm{A}$ genotype, but not $M M P-13$ genotypes, was connected with a higher risk of disseminated CRC. ${ }^{85}$

The MMP-14 SNPs, including $-165 \mathrm{~T}>\mathrm{G}, 221 \mathrm{~T}>\mathrm{C}$, $6727 \mathrm{C}>\mathrm{G}, 6767 \mathrm{G}>\mathrm{A}, 7096 \mathrm{~T}>\mathrm{C}$, and $8153 \mathrm{G}>\mathrm{A}$ have been validated to correlate with risk of HCC in Taiwan. Individuals with the $M M P-146767 \mathrm{G} / \mathrm{A}$ or $7096 \mathrm{C} / \mathrm{C}$ genotype exhibited a significantly lower risk of HCC. ${ }^{86}$ There was no significant difference in the genotype distributions and allele frequencies of TIMP -2 303C $>\mathrm{T}$ between GC patients and controls in a German population. The correlations between the determined SNPs and clinicopathological parameters showed that patients with the CC genotype had significantly higher lymph node metastasis and more distant metastasis. ${ }^{65}$ In CRC, two SNPs at promoter -418 and -303 of $T M P-2$ were assayed in a Korean population. The homozygous TIMP-2 -418 G/G and TIMP-2 -303 G/G genotypes were significantly more frequent in $\mathrm{CRC}$ patients than in healthy controls. Individuals with the TIMP-2 $-418 \mathrm{C} / \mathrm{C}$ genotype were more frequent in 
CRC patients with a family history of cancer. The frequency of the TIMP-2 -418 G/G genotype was significantly higher in CRC patients with distant metastasis than in those without distant metastasis. ${ }^{82}$

\section{miRNA regulation of MMPs and TIMPs}

In ESCC, MMP-14 has been identified as an independent poor prognostic factor. A bioinformatic analysis identified one conserved sequence site for miR-133a in the 3 -untranslated region of $M M P-14$. The expression levels of miR-133a were significantly lower in the tumor tissues than in the normal tissues. MMP-14 mRNA levels in surgical specimens significantly inversely correlated with miR-133a. Transfection of the miR-133a inhibitor significantly increased $M M P-14$ mRNA levels. Knockdown of MMP-14 or transfection of an miR-133a mimic inhibits the proliferation and invasion of ESCC cells. ${ }^{87}$ miR-21 downregulation can inhibit the metastasis of ESCC by targeting TIMP-3.88

In GC, downregulation of miR-148a GC tissues was reported by using an mRNA microarray. In oligonucleotide array analysis, $M M P-7$ was markedly downregulated in miR-148a-overexpressing GC cells. $M M P-7$ was found to be

Table 3 MMPs and TIMPs are targeted directly or indirectly by miRNAs in gastrointestinal cancers

\begin{tabular}{|c|c|c|c|}
\hline $\begin{array}{l}\text { MMPs/ } \\
\text { TIMPs }\end{array}$ & miRNAs & $\begin{array}{l}\text { Cancer } \\
\text { type }\end{array}$ & Target \\
\hline \multirow[t]{4}{*}{ MMP-2 } & miR-29a & $\mathrm{CRC}^{93}$ & $\begin{array}{l}\text { Target KLF4, and then indirectly } \\
\text { downregulate its downstream MMP-2 }\end{array}$ \\
\hline & miR-29b & CRC; ${ }^{44}$ & Target MMP-2 directly \\
\hline & & $\mathrm{HCC}^{45}$ & \\
\hline & miR-139 & $\mathrm{CRC}^{94}$ & $\begin{array}{l}\text { Target IGF-IR, and then indirectly } \\
\text { downregulate its downstream MMP-2 } \\
\text { via IGF-IR/MEK/ERK signaling }\end{array}$ \\
\hline MMP-7 & miR-I48a & $\mathrm{GC}^{89}$ & Target MMP-7 directly \\
\hline \multirow[t]{2}{*}{ MMP-9 } & miR-I45 & $\mathrm{GC}^{90}$ & $\begin{array}{l}\text { Target N-cadherin, and then } \\
\text { indirectly downregulate its } \\
\text { downstream MMP-9 }\end{array}$ \\
\hline & miR-49I & $\mathrm{HCC}^{97}$ & Target MMP-9 directly \\
\hline \multirow[t]{2}{*}{ MMP-II } & miR-125a & $\mathrm{HCC}^{99}$ & Target MMP-I/ directly \\
\hline & let-7c & $\mathrm{CRC}^{95}$ & Target MMP-I/ directly \\
\hline \multirow[t]{2}{*}{ MMP-I4 } & miR-I33a & $\mathrm{ESCC}^{87}$ & Target MMP-I 4 directly \\
\hline & let-7 & $P^{102}$ & Target MMP-I4 indirectly \\
\hline TIMP-2 & miR-I06a & $\mathrm{GC}:{ }^{53} \mathrm{PC}^{54}$ & Target TIMP-2 directly \\
\hline \multirow[t]{3}{*}{ TIMP-3 } & miR-2I & $\mathrm{ESCC}^{88}$ & Target TIMP-3 directly \\
\hline & miR-I8Ib, & $\mathrm{HCC}^{101}$ & Target TIMP-3 directly \\
\hline & $\begin{array}{l}\text { miR-I8Id, } \\
\text { miR-2II, } \\
\text { miR-222 }\end{array}$ & $\mathrm{HCC}^{100}$ & Target TIMP-3 directly \\
\hline
\end{tabular}

Abbreviations: CRC, colorectal cancer; ESCC, esophageal squamous cell carcinoma; GS, gastric cancer; HCC, hepatocellular carcinoma; miRNA, microRNA; MMP, matrix metalloproteinase; PC, pancreatic cancer; TIMP, tissue inhibitor of metalloproteinase. a direct and functional target of miR-148a, participating in cell invasion. ${ }^{89} \mathrm{MiR}-145$ suppressed the invasion-metastasis cascade in GC by directly targeting $\mathrm{N}$-cadherin protein translation and then indirectly downregulated its downstream effector MMP-9. ${ }^{90}$ TIMP-2 was found to be the target of miR-106a. Upregulated miR-106a positively adjusted GC cell proliferation, migration, and invasion. Knockdown of TIMP-2 could mimic the miR-106a-induced cancer development benefits. Inverse correlation of miR-106a and TIMP-2 ultimately contributed to the enhancement of GC progression..$^{91}$

Three reports have implicated miRNAs in the direct or indirect regulation of $M M P-2$ in CRC. It was found that high expression of miR-29a and miR-29b promoted cancer metastasis by upregulation of MMP-2 through targeting KLF4 in colorectal tumorigenesis. ${ }^{92,93}$ In CRC, decreased miR-139 was found to be associated with invasion and metastasis. Downregulation of miR-139 promotes migration inactivation of CRC cells by increasing MMP-2 through targeting type I IGF-IR and regulating downstream MEK/ERK signaling. ${ }^{94}$ Downregulation of let-7c in cancer tissues was significantly associated with metastases, advanced TNM stage, and poor survival of CRC patients. ${ }^{95}$

Downregulation of miR-29b was associated with poor recurrence-free survival of HCC patients. In human HCC tissues and mouse xenograft tumors, miR-29b levels were inversely correlated with MMP-2 expression as well as tumor angiogenesis, venous invasion, and metastasis. ${ }^{96}$ Through miRNA microarray analysis, miR-491 level was significantly downregulated in poorly differentiated HCC tissue compared with well-differentiated HCC tissue. miR-491 levels were also inversely correlated with different status of differentiation in HCC tissues and with migratory potential in HCC cell lines. ${ }^{97} \mathrm{miR}-491$ was predicted to bind the MMP-9 mRNA 3'-untranslated region via TargetScan (http://www.targetscan.org/) and microRNA.org (http:// www.microrna.org/microrna/home.do) algorithms. A study of glioblastoma multiforme suggests that miR-491 is the $M M P$-9-specific miRNA, which downregulates $M M P-9$ mRNA directly. ${ }^{98}$ miR-125a was frequently downregulated in HCC compared with matched adjacent liver tissues, and correlated with the malignant progression of patients. miR125a inhibits the proliferation and metastasis of HCC by targeting MMP-11. ${ }^{99}$ TIMP-3 was identified as a target of miR-181b, miR-181d, miR-221, and miR-222. ${ }^{100,101}$ In a diet-induced HCC mouse model, miR-181b and miR-181d levels were upregulated. mir-181b target TIMP-3 mRNA leads to downregulation of TIMP-3 level and subsequent 
enhancement of MMP-2 and MMP-9 activities, promoting migration and invasion. ${ }^{101} \mathrm{miR}-221$ and $\mathrm{miR}-222$ were found to be increased in HCC to target TIMP-3 and PTEN due to the activation of MMP-3, MMP-9, and the AKT pathway. ${ }^{100}$

In pancreatic ductal adenocarcinoma, MMP-14 expression significantly correlated with decreased levels of let-7 in human pancreatic ductal adenocarcinoma tumor specimens. Let-7 indirectly regulates the expression of MMP-14 and ERK1/2 activation. ${ }^{102}$ In addition, a high level of miR-106a expression has an oncogenic role in pancreatic tumorigenesis by targeting TIMP-2. ${ }^{103}$

\section{Clinical potential}

The imbalance between MMPs and TIMPs can facilitate the early carcinogenesis, tumor development, growth, invasion, and metastasis of cancer cells. Alternative expressions of MMPs and TIMPs have been found in ESCC, GC, CRC, $\mathrm{HCC}$, and even pancreatic cancer. It indicates that the concentrations of various MMPs and TIMPs are upregulated in the tissue, plasma, or even serum of cancer patients and may thus correlate with the tumor stage, depth of tumor invasion, presence of nodal, distant metastases, and patient survival. Therefore, these MMPs and TIMPs can be applied as diagnostic or prognostic markers for these cancers. The control of MMP activity may thus be generated as a potential therapeutic target to inhibit tumor progression. SNP analysis also offers the potential for a better diagnosis of various diseases and prediction of clinical outcome and therapeutic efficiency in several cancers. To predict the cancer risk in a population and the outcome, several genes would probably be a better tool than the use of a single SNP. Alternative expressions of miRNAs are also disclosed in a variety of cancers. MMP and TIMP levels are exactly regulated by miRNAs in either a direct or indirect manner. Utilization of miRNA mimics may thus provide inhibition of cancer progression via targeting the related MMPs or their upstream regulators.

\section{Disclosure}

The authors report no conflicts of interest in this work.

\section{References}

1. Madlener M, Parks WC, Werner S. Matrix metalloproteinases (MMPs) and their physiological inhibitors (TIMPs) are differentially expressed during excisional skin wound repair. Exp Cell Res. 1998;242(1):201-210.

2. Hua H, Li M, Luo T, Yin Y, Jiang Y. Matrix metalloproteinases in tumorigenesis: an evolving paradigm. Cell Mol Life Sci. 2011;68(23): 3853-3868

3. Yeh YC, Sheu BS, Cheng HC, Wang YL, Yang HB, Wu JJ. Elevated serum matrix metalloproteinase-3 and -7 in H. pylori-related gastric cancer can be biomarkers correlating with a poor survival. Dig Dis Sci. 2010;55(6):1649-1657.
4. van der Jagt MF, Wobbes T, Strobbe LJ, Sweep FC, Span PN. Metalloproteinases and their regulators in colorectal cancer. $J$ Surg Oncol. 2010;101(3):259-269.

5. Wang WL, Chang WL, Yeh YC, et al. Concomitantly elevated serum matrix metalloproteinases 3 and 9 can predict survival of synchronous squamous cell carcinoma of the upper aero-digestive tract. Mol Carcinog. 2013;52(6):438-445.

6. Sun XF, Zhang H. Clinicopathological significance of stromal variables: angiogenesis, lymphangiogenesis, inflammatory infiltration, MMP and PINCH in colorectal carcinomas. Mol Cancer. 2006;5:43.

7. Paschos KA, Canovas D, Bird NC. Enzymatic function of multiple origins regulates the progression of colorectal cancer and the development of metastases. Hippokratia. 2009;13(1):23-31.

8. Amalinei C, Caruntu ID, Giusca SE, Balan RA. Matrix metalloproteinases involvement in pathologic conditions. Rom J Morphol Embryol. 2010;51(2):215-228.

9. Gomez DE, Alonso DF, Yoshiji H, Thorgeirsson UP. Tissue inhibitors of metalloproteinases: structure, regulation and biological functions. Eur J Cell Biol. 1997;74(2):111-122.

10. Baker AH, Edwards DR, Murphy G. Metalloproteinase inhibitors: biological actions and therapeutic opportunities. J Cell Sci. 2002; 115(Pt 19):3719-3727.

11. Lambert E, Dasse E, Haye B, Petitfrere E. TIMPs as multifacial proteins. Crit Rev Oncol Hematol. 2004;49(3):187-198.

12. Stetler-Stevenson WG. Matrix metalloproteinases in angiogenesis: a moving target for therapeutic intervention. J Clin Invest. 1999;103(9): 1237-1241.

13. Amour A, Slocombe PM, Webster A, et al. TNF- $\alpha$ converting enzyme (TACE) is inhibited by TIMP-3. FEBS Lett. 1998;435(1):39-44.

14. Brew K, Dinakarpandian D, Nagase H. Tissue inhibitors of metalloproteinases: evolution, structure, and function. Biochim Biophys Acta. 2000;1477(1-2):267-283.

15. Greene J, Wang M, Liu YE, Raymond LA, Rosen C, Shi YE. Molecular cloning and characterization of human tissue inhibitor of metalloproteinase 4. J Biol Chem. 1996;271(48):30375-30380.

16. Leco KJ, Apte SS, Taniguchi GT, et al. Murine tissue inhibitor of metalloproteinases-4 (Timp-4): cDNA isolation and expression in adult mouse tissues. FEBS Lett. 1997;401(2-3):213-217.

17. LiY, Ma J, Guo Q, et al. Overexpression of MMP-2 and MMP-9 in esophageal squamous cell carcinoma. Dis Esophagus. 2009;22(8):664-667.

18. Lukaszewicz-Zajac M, Mroczko B, Kozlowski M, Niklinski J, Laudanski J, Szmitkowski M. Elevated levels of serum metalloproteinase 9 in patients with esophageal squamous cell carcinoma. Pol Arch Med Wewn. 2009;119(9):558-563.

19. Mukherjee S, Roth MJ, Dawsey SM, Yan W, et al. Increased matrix metalloproteinase activation in esophageal squamous cell carcinoma. J Transl Med. 2010;8:91.

20. Liu H, Qin YR, Bi J, Guo A, Fu L, Guan XY. Overexpression of matrix metalloproteinase 10 is associated with poor survival in patients with early stage of esophageal squamous cell carcinoma. Dis Esophagus. 2012;25(7):656-663.

21. Peng HH, Zhang X, Cao PG. MMP-1/PAR-1 signal transduction axis and its prognostic impact in esophageal squamous cell carcinoma. Braz J Med Biol Res. 2012;45(1):86-92.

22. Tao YS, Ma XY, Chai DM, et al. Overexpression of MMP-1 and VEGF-C is associated with a less favorable prognosis in esophageal squamous cell carcinoma. Onkologie. 2012;35(11):651-656.

23. LiY, Guo H, Dong D, Wu H, Li E. Expression and prognostic relevance of cyclophilin A and matrix metalloproteinase 9 in esophageal squamous cell carcinoma. Diagn Pathol. 2013;8:207.

24. Jiao XL, Chen D, Wang JG, Zhang KJ. Clinical significance of serum matrix metalloproteinase-13 levels in patients with esophageal squamous cell carcinoma (ESCC). Eur Rev Med Pharmacol Sci. 2014;18(4):509-515.

25. Maurer J, Schopp M, Thurau K, Haier J, Kohler G, Hummel R. Immunohistochemical analysis on potential new molecular targets for esophageal cancer. Dis Esophagus. 2014;27(1):93-100. 
26. Ye Q, Yan Z, Liao X, et al. MUC1 induces metastasis in esophageal squamous cell carcinoma by upregulating matrix metalloproteinase 13 . Lab Invest. 2011;91(5):778-787.

27. Chen L, Di D, Luo G, et al. Immunochemical staining of MT2-MMP correlates positively to angiogenesis of human esophageal cancer. Anticancer Res. 2010;30(10):4363-4368.

28. Ninomiya I, Kawakami K, Fushida S, et al. Quantitative detection of TIMP-3 promoter hypermethylation and its prognostic significance in esophageal squamous cell carcinoma. Oncol Rep. 2008;20(6): 1489-1495.

29. Groblewska M, Mroczko B, Kozlowski M, Niklinski J, Laudanski J, Szmitkowski M. Serum matrix metalloproteinase 2 and tissue inhibitor of matrix metalloproteinases 2 in esophageal cancer patients. Folia Histochem Cytobiol. 2012;50(4):590-598.

30. Liu HQ, Song S, Wang JH, Zhang SL. Expression of MMP-3 and TIMP-3 in gastric cancer tissue and its clinical significance. Oncol Lett. 2011;2(6):1319-1322.

31. Cai QW, Li J, Li XQ, Wang JQ, Huang Y. Expression of STAT3, MMP-1 and TIMP-1 in gastric cancer and correlation with pathological features. Mol Med Rep. 2012;5(6):1438-1442.

32. Zheng J, Chu D, Wang D, et al. Matrix metalloproteinase-12 is associated with overall survival in Chinese patients with gastric cancer. J Surg Oncol. 2013;107(7):746-751.

33. de la Pena S, Sampieri CL, Ochoa-Lara M, Leon-Cordoba K, RemesTroche JM. Expression of the matrix metalloproteases 2, 14, 24, and 25 and tissue inhibitor 3 as potential molecular markers in advanced human gastric cancer. Dis Markers. 2014;2014:285906.

34. Li Z, Zhang D, Zhang H, et al. Prediction of peritoneal recurrence by the mRNA level of CEA and MMP-7 in peritoneal lavage of gastric cancer patients. Tumour Biol. 2014;35(4):3463-3470.

35. Chung WC, Jung SH, Lee KM, et al. The detection of Helicobacter pylori cag pathogenicity islands (PAIs) and expression of matrix metalloproteinase-7 (MMP-7) in gastric epithelial dysplasia and intramucosal cancer. Gastric Cancer. 2010;13(3):162-169.

36. Wu T, Li Y, Lu J, et al. Increased MMP-21 expression is associated with poor overall survival of patients with gastric cancer. Med Oncol. 2013;30(1):323.

37. Peng CW, Wang LW, Fang M, Yang GF, Li Y, Pang DW. Combined features based on MT1-MMP expression, CD11b + immunocytes density and LNR predict clinical outcomes of gastric cancer. $J$ Transl Med. 2013;11:153.

38. Kemik O, Kemik AS, Sumer A, et al. Levels of matrix metalloproteinase-1 and tissue inhibitors of metalloproteinase-1 in gastric cancer. World J Gastroenterol. 2011;17(16):2109-2112.

39. Mroczko B, Lukaszewicz-Zajac M, Gryko M, Kedra B, Szmitkowski M. Clinical significance of serum levels of matrix metalloproteinase 2 (MMP-2) and its tissue inhibitor (TIMP-2) in gastric cancer. Folia Histochem Cytobiol. 2011;49(1):125-131.

40. Kanazawa A, Oshima T, Yoshihara K, et al. Relation of MT1-MMP gene expression to outcomes in colorectal cancer. J Surg Oncol. 2010;102(6): 571-575.

41. Yamada T, Oshima T, Yoshihara K, et al. Overexpression of MMP-13 gene in colorectal cancer with liver metastasis. Anticancer Res. 2010;30(7):2693-2699.

42. Wu T, Li Y, Liu X, et al. Identification of high-risk stage II and stage III colorectal cancer by analysis of MMP-21 expression. J Surg Oncol. 2011;104(7):787-791.

43. Langers AM, Verspaget HW, Hawinkels LJ, et al. MMP-2 and MMP-9 in normal mucosa are independently associated with outcome of colorectal cancer patients. Br J Cancer. 2012;106(9):1495-1498.

44. Langenskiold M, Ivarsson ML, Holmdahl L, Falk P, Kabjorn-Gustafsson C, Angenete E. Intestinal mucosal MMP-1 - a prognostic factor in colon cancer. Scand J Gastroenterol. 2013;48(5):563-569.

45. Vayrynen JP, Vornanen J, Tervahartiala T, et al. Serum MMP-8 levels increase in colorectal cancer and correlate with disease course and inflammatory properties of primary tumors. Int J Cancer. 2012;131(4): E463-E474.
46. Mroczko B, Groblewska M, Okulczyk B, Kedra B, Szmitkowski M. The diagnostic value of matrix metalloproteinase 9 (MMP-9) and tissue inhibitor of matrix metalloproteinases 1 (TIMP-1) determination in the sera of colorectal adenoma and cancer patients. Int $J$ Colorectal Dis. 2010;25(10):1177-1184.

47. Xiang ZL, Zeng ZC, Fan J, Tang ZY, Zeng HY, Gao DM. Gene expression profiling of fixed tissues identified hypoxia-inducible factor- $1 \alpha$, VEGF, and matrix metalloproteinase-2 as biomarkers of lymph node metastasis in hepatocellular carcinoma. Clin Cancer Res. 2011;17(16):5463-5472.

48. Chen R, Cui J, Xu C, et al. The significance of MMP-9 over MMP-2 in HCC invasiveness and recurrence of hepatocellular carcinoma after curative resection. Ann Surg Oncol. 2012;19(Suppl 3):S375-S384.

49. Liao M, Tong $\mathrm{P}$, Zhao J, et al. Prognostic value of matrix metalloproteinase-1/proteinase-activated receptor-1 signaling axis in hepatocellular carcinoma. Pathol Oncol Res. 2012;18(2):397-403.

50. Ng KT, Qi X, Kong KL, et al. Overexpression of matrix metalloproteinase-12 (MMP-12) correlates with poor prognosis of hepatocellular carcinoma. Eur J Cancer. 2011;47(15):2299-2305.

51. Lempinen M, Lyytinen I, Nordin A, et al. Prognostic value of serum MMP-8, -9 and TIMP-1 in patients with hepatocellular carcinoma. Ann Med. 2013;45(7):482-487.

52. Poruk KE, Firpo MA, Scaife CL, et al. Serum osteopontin and tissue inhibitor of metalloproteinase 1 as diagnostic and prognostic biomarkers for pancreatic adenocarcinoma. Pancreas. 2013;42(2):193-197.

53. Bartel DP. MicroRNAs: target recognition and regulatory functions. Cell. 2009;136(2):215-233.

54. Shukla GC, Singh J, Barik S. MicroRNAs: processing, maturation, target recognition, and regulatory functions. Mol Cell Pharmacol. 2011;3(3): 83-92.

55. Feber A, Xi L, Pennathur A, et al. MicroRNA prognostic signature for nodal metastases and survival in esophageal adenocarcinoma. Ann Thorac Surg. 2011;91(5):1523-1530.

56. He B, Yin B, Wang B, Xia Z, Chen C, Tang J. MicroRNAs in esophageal cancer. Mol Med Rep. 2012;6(3):459-465.

57. Hermeking H. MicroRNAs in the p53 network: micromanagement of tumour suppression. Nat Rev Cancer. 2012;12(9):613-626.

58. Rutter JL, Mitchell TI, Buttice G, et al. A single nucleotide polymorphism in the matrix metalloproteinase-1 promoter creates an Ets binding site and augments transcription. Cancer Res. 1998;58(23):5321-5325.

59. Kouhkan F, Motovali-Bashi M, Hojati Z. The influence of interstitial collagenase-1 genotype polymorphism on colorectal cancer risk in Iranian population. Cancer Invest. 2008;26(8):836-842.

60. Fang WL, Liang WB, He H, et al. Association of matrix metalloproteinases 1,7 , and 9 gene polymorphisms with genetic susceptibility to colorectal carcinoma in a Han Chinese population. DNA Cell Biol. 2010;29(11):657-661.

61. Dey S, Ghosh N, Saha D, Kesh K, Gupta A, Swarnakar S. Matrix metalloproteinase-1 (MMP-1) promoter polymorphisms are well linked with lower stomach tumor formation in eastern Indian population. PLoS One. 2014;9(2):e88040.

62. Price SJ, Greaves DR, Watkins H. Identification of novel, functional genetic variants in the human matrix metalloproteinase-2 gene: role of Sp1 in allele-specific transcriptional regulation. $J$ Biol Chem. 2001;276(10):7549-7558.

63. LiY, Sun DL, Duan YN, et al. Association of functional polymorphisms in MMPs genes with gastric cardia adenocarcinoma and esophageal squamous cell carcinoma in high incidence region of North China. Mol Biol Rep. 2010;37(1):197-205.

64. Langers AM, Sier CF, Hawinkels LJ, et al. MMP-2 geno-phenotype is prognostic for colorectal cancer survival, whereas MMP-9 is not. Br J Cancer. 2008;98(11):1820-1823.

65. Alakus H, Afriani N, Warnecke-Eberz U, et al. Clinical impact of MMP and TIMP gene polymorphisms in gastric cancer. World J Surg. 2010;34(12):2853-2859.

66. Kang MJ, Jung SA, Jung JM, et al. Associations between single nucleotide polymorphisms of MMP2, VEGF, and HIF1A genes and the risk of developing colorectal cancer. Anticancer Res. 2011;31(2):575-584. 
67. Ting WC, Chen LM, Pao JB, et al. Genetic polymorphisms of matrix metalloproteinases and clinical outcomes in colorectal cancer patients. Int J Med Sci. 2013;10(8):1022-1027.

68. Ye S, Eriksson P, Hamsten A, Kurkinen M, Humphries SE, Henney AM. Progression of coronary atherosclerosis is associated with a common genetic variant of the human stromelysin-1 promoter which results in reduced gene expression. J Biol Chem. 1996;271(22): 13055-13060.

69. Okamoto K, Ishida C, Ikebuchi Y, et al. The genotypes of IL-1 beta and MMP-3 are associated with the prognosis of HCV-related hepatocellular carcinoma. Intern Med. 2010;49(10):887-895.

70. Sugimoto M, Furuta T, Kodaira C, et al. Polymorphisms of matrix metalloproteinase-7 and chymase are associated with susceptibility to and progression of gastric cancer in Japan. J Gastroenterol. 2008;43(10): 751-761.

71. Dziki L, Przybylowska K, Majsterek I, Trzcinski R, Mik M, Sygut A. $\mathrm{A} / \mathrm{G}$ polymorphism of the MMP-7 gene promoter region in colorectal cancer. Pol Przegl Chir. 2011;83(11):622-626.

72. Malik MA, Sharma KL, Zargar SA, Mittal B. Association of matrix metalloproteinase-7 $(-181 \mathrm{~A}>\mathrm{G})$ polymorphism with risk of esophageal squamous cell carcinoma in Kashmir Valley. Saudi J Gastroenterol. 2011;17(5):301-306.

73. Malik MA, Zargar SA, Mittal B. Role of the metalloproteinase-7 $(181 \mathrm{~A}>\mathrm{G})$ polymorphism in gastric cancer susceptibility: a case control study in Kashmir valley. Asian Pac J Cancer Prev. 2011;12(1): $73-76$.

74. Jormsjo S, Whatling C, Walter DH, Zeiher AM, Hamsten A, Eriksson P. Allele-specific regulation of matrix metalloproteinase-7 promoter activity is associated with coronary artery luminal dimensions among hypercholesterolemic patients. Arterioscler Thromb Vasc Biol. 2001;21(11):1834-1839.

75. Kroeger PE, Sarge KD, Morimoto RI. Mouse heat shock transcription factors 1 and 2 prefer a trimeric binding site but interact differently with the HSP70 heat shock element. Mol Cell Biol. 1993;13(6): 3370-3383.

76. Zhang B, Ye S, Herrmann SM, et al. Functional polymorphism in the regulatory region of gelatinase $\mathrm{B}$ gene in relation to severity of coronary atherosclerosis. Circulation. 1999;99(14):1788-1794.

77. Shipley JM, Doyle GA, Fliszar CJ, et al. The structural basis for the elastolytic activity of the $92-\mathrm{kDa}$ and $72-\mathrm{kDa}$ gelatinases. Role of the fibronectin type II-like repeats. J Biol Chem. 1996;271(8): 4335-4341.

78. Pisani P, Parkin DM, Bray F, Ferlay J. Estimates of the worldwide mortality from 25 cancers in 1990. Int J Cancer. 1999;83(1):18-29.

79. Wu J, Zhang L, Luo H, Zhu Z, Zhang C, Hou Y. Association of matrix metalloproteinases-9 gene polymorphisms with genetic susceptibility to esophageal squamous cell carcinoma. DNA Cell Biol. 2008;27(10): $553-557$.

80. Tang Y, Zhu J, Chen L, Chen L, Zhang S, Lin J. Associations of matrix metalloproteinase-9 protein polymorphisms with lymph node metastasis but not invasion of gastric cancer. Clin Cancer Res. 2008;14(9): 2870-2877.

81. Yang ZH, Li SN, Liu JX, Guo QX, Sun XW. MMP-9 polymorphisms are related to serum lipids levels but not associated with colorectal cancer susceptibility in Chinese population. Mol Biol Rep. 2012;39(10): 9399-9404

82. Park KS, Kim SJ, Kim KH, Kim JC. Clinical characteristics of TIMP2, MMP2, and MMP9 gene polymorphisms in colorectal cancer. J Gastroenterol Hepatol. 2011;26(2):391-397.

83. Jormsjo S, Ye S, Moritz J, et al. Allele-specific regulation of matrix metalloproteinase-12 gene activity is associated with coronary artery luminal dimensions in diabetic patients with manifest coronary artery disease. Circ Res. 2000;86(9):998-1003.

84. Yoon S, Kuivaniemi H, Gatalica Z, et al. MMP13 promoter polymorphism is associated with atherosclerosis in the abdominal aorta of young black males. Matrix Biol. 2002;21(6):487-498.
85. Van Nguyen S, Skarstedt M, Lofgren S,. Gene polymorphism of matrix metalloproteinase-12 and -13 and association with colorectal cancer in Swedish patients. Anticancer Res. 2013;33(8):3247-3250.

86. Chen TY, Li YC, Liu YF, et al. Role of MMP14 gene polymorphisms in susceptibility and pathological development to hepatocellular carcinoma. Ann Surg Oncol. 2011;18(8):2348-2356.

87. Akanuma N, Hoshino I, Akutsu Y, et al. MicroRNA-133a regulates the mRNAs of two invadopodia-related proteins, FSCN1 and MMP14, in esophageal cancer. Br J Cancer. 2014;110(1):189-198.

88. Wang N, Zhang CQ, He JH, et al. MiR-21 down-regulation suppresses cell growth, invasion and induces cell apoptosis by targeting FASL, TIMP3, and RECK genes in esophageal carcinoma. Dig Dis Sci. 2013;58(7):1863-1870.

89. Sakamoto N, Naito Y, Oue N, et al. MicroRNA-148a is downregulated in gastric cancer, targets MMP7, and indicates tumor invasiveness and poor prognosis. Cancer Sci. 2014;105(2):236-243.

90. Gao P, Xing AY, Zhou GY, et al. The molecular mechanism of microRNA-145 to suppress invasion-metastasis cascade in gastric cancer. Oncogene. 2013;32(4):491-501.

91. Zhu M, Zhang N, He S, Lui Y, Lu G, Zhao L. MicroRNA-106a targets TIMP2 to regulate invasion and metastasis of gastric cancer. FEBS Lett. 2014;588(4):600-607.

92. Poudyal D, Cui X, Le PM, et al. A key role of microRNA-29b for the suppression of colon cancer cell migration by American ginseng. PLoS One. 2013;8(10):e75034.

93. Tang W, Zhu Y, Gao J, et al. MicroRNA-29a promotes colorectal cancer metastasis by regulating matrix metalloproteinase 2 and E-cadherin via KLF4. Br J Cancer. 2014;110(2):450-458.

94. Shen K, Liang Q, Xu K, et al. MiR-139 inhibits invasion and metastasis of colorectal cancer by targeting the type I insulin-like growth factor receptor. Biochem Pharmacol. 2012;84(3):320-330.

95. Han HB, Gu J, Zuo HJ, et al. Let-7c functions as a metastasis suppressor by targeting MMP11 and PBX3 in colorectal cancer. J Pathol. 2012;226(3):544-555

96. Fang JH, Zhou HC, Zeng C, et al. MicroRNA-29b suppresses tumor angiogenesis, invasion, and metastasis by regulating matrix metalloproteinase 2 expression. Hepatology. 2011;54(5):1729-1740.

97. Zhou Y, Li Y, Ye J, et al. MicroRNA-491 is involved in metastasis of hepatocellular carcinoma by inhibitions of matrix metalloproteinase and epithelial to mesenchymal transition. Liver Int. 2013;33(8): 1271-1280.

98. Yan W, Zhang W, Sun L, et al. Identification of MMP-9 specific microRNA expression profile as potential targets of anti-invasion therapy in glioblastoma multiforme. Brain Res. 2011;1411: $108-115$.

99. Bi Q, Tang S, Xia L, et al. Ectopic expression of MiR-125a inhibits the proliferation and metastasis of hepatocellular carcinoma by targeting MMP11 and VEGF. PLoS One. 2012;7(6):e40169.

100. Garofalo M, Di Leva G, Romano G, et al. miR-221\&222 regulate TRAIL resistance and enhance tumorigenicity through PTEN and TIMP3 downregulation. Cancer Cell. 2009;16(6):498-509.

101. Wang B, Hsu SH, Majumder S, et al. TGF $\beta$-mediated upregulation of hepatic miR-181b promotes hepatocarcinogenesis by targeting TIMP3. Oncogene. 2010;29(12):1787-1797.

102. Dangi-Garimella S, Strouch MJ, Grippo PJ, Bentrem DJ, Munshi HG. Collagen regulation of let-7 in pancreatic cancer involves TGF- $\beta 1$ mediated membrane type 1-matrix metalloproteinase expression. Oncogene. 2011;30(8):1002-1008.

103. Li P, Xu Q, Zhang D, et al. Upregulated miR-106a plays an oncogenic role in pancreatic cancer. FEBS Lett. 2014;588(5):705-712.

104. Kashyap MK, Marimuthu A, Kishore CJ, et al. Genomewide mRNA profiling of esophageal squamous cell carcinoma for identification of cancer biomarkers. Cancer Biol Ther. 2009;8(1):36-46.

105. Murnane MJ, Cai J, Shuja S, McAneny D, Klepeis V, Willett JB. Active MMP-2 effectively identifies the presence of colorectal cancer. Int J Cancer. 2009;125(12):2893-2902. 
106. Koskensalo S, Louhimo J, Nordling S, Hagstrom J, Haglund C. MMP-7 as a prognostic marker in colorectal cancer. Tumour Biol. 2011;32(2):259-264.

107. Bendardaf R, Buhmeida A, Hilska M, et al. MMP-9 (gelatinase B) expression is associated with disease-free survival and diseasespecific survival in colorectal cancer patients. Cancer Invest. 2010;28(1):38-43.
108. Jensen SA, Vainer B, Bartels A, Brunner N, Sorensen JB. Expression of matrix metalloproteinase 9 (MMP-9) and tissue inhibitor of metalloproteinases 1 (TIMP-1) by colorectal cancer cells and adjacent stroma cells - associations with histopathology and patients outcome. Eur J Cancer. 2010;46(18):3233-3242.

109. Durlik M, Gardian K. Metalloproteinase 2 and 9 activity in the development of pancreatic cancer. Pol Przegl Chir. 2012;84(8):377-382.

\section{Publish your work in this journal}

Metalloproteinases In Medicine is an international, peer reviewed, open access journal that aims to provide a platform for the discussion and dissemination of knowledge about the role that metalloproteinases - such as matrix metalloproteinases (MMP), ADAMs, ADAMTSs, and astacins, as well as their inhibitors - play in diseases.

\section{Dovepress}

The manuscript management system is completely online and includes a very quick and fair peer review system, which is all easy to use. Visit http://www.dovepress.com/testimonials.php to read real quotes from published authors.

Submit your manuscript here: http://www.dovepress.com/metalloproteinases-in-medicine-journal 